\title{
BERPIKIR KREATIF DALAM FISIKA DENGAN PEMBELAJARAN CONCEPTUAL UNDERSTANDING PROCEDURES (CUPS) BERBANTUAN LKPD
}

\author{
Nurul Fitriani, Gunawan, Sutrio \\ Program Studi Pendidikan Fisika \\ Universitas Mataram \\ Jalan Majapahit No. 62, Mataram \\ E-Mail: nurulfitriani2juni94@,gmail.com
}

\begin{abstract}
$\overline{\text { Abstract - This study aims to improve students' creative thinking ability in physics by using conceptual }}$ understanding learning learning with LKPD. This quasi experimental study uses non-equivalent control group design. The population is all students of class XMA NW Narmada. The sample was chosen using purposive sampling technique which consist of class XB students as experiment class and XA class student as control class. The research instrument uses verbal and figural creativity tests that have been validated by experts. Hypothesis test using t-pooled variance test. Increased creativity is determined based on the results of the $N$ gain test. The results showed that there was an increase of students' creativity in both classes. Verbal and figural creativity improves in both classes. The experimental class experienced a higher creativity increase than the control class. Verbal creativity increased higher than the figural creativity. This shows that LKPD conceptual understanding procedure model applied successfully improve the creativity of learners in physics learning.
\end{abstract}

Keywords: Learning CUPs, LKPD, Creative Thinking in Physics.

\section{PENDAHULUAN}

Ilmu pengetahuan alam (IPA) merupakan ilmu yang berkaitan dengan cara mencari tahu tentang alam secara sistematis sehingga IPA bukan hanya penguasaan kumpulan pengetahuan berupa fakta-fakta, konsep-konsep, atau prinsip-prinsip saja, tetapi juga merupakan suatu proses penemuan. IPA adalah ilmu pengetahuan yang mempelajari gejala-gejala melalui serangkaian proses yang dikenal dengan proses ilmiah, yang dibangun atas dasar sikap ilmiah dan hasilnya terwujud sebagai produk ilmiah yang tersusun atas tiga komponen terpenting berupa konsep, prinsip, dan teori yang berlaku secara umum (Trianto, 2011). Konsep yang dimaksud adalah ide yang mempersatukan faktafakta atau dengan kata lain konsep merupakan suatu penghubung antara fakta-fakta yang saling berhubungan. Kemudian prinsip adalah hubungan antara konsep-konsep yang berkaitan, sedangkan teori adalah berbagai prinsip yang dapat menjelaskan fenomena alam.

Fisika merupakan bagian dari sains yang memfokuskan kajiannya pada materi, energi, dan hubungan antara keduanya (Gunawan et al, 2015).
Fisika juga merupakan bagian dari ilmu sains yang pada hakikatnya merupakan kumpulan pengetahuan, cara berpikir, dan penyelidikan. Ilmu sains yang dimaksud adalah ilmu pengetahuan yang mempelajari sifat dan gejala pada benda-benda di alam. Gejala-gejala ini pada awalnya adalah apa yang dialami oleh indra kita, misalnya penglihatan menemukan optika atau cahaya, pendengaran menemukan pelajaran tentang bunyi, dan indra peraba yang dapat merasakan panas.

Pendidikan adalah usaha sadar dan terencana untuk mewujudkan suasana belajar dan proses pembelajaran agar peserta didik secara aktif mengembangkan potensi dirinya untuk memiliki kekuatan spiritual, keagamaan, pengendalian diri, kepribadian, kecerdasan, akhlak mulia, serta keterampilan yang diperlukan dirinya, masyarakat, bangsa, dan negara. Pendidikan merupakan sarana pewarisan keterampilan hidup sehingga keterampilan yang telah ada pada satu generasi dapat dilestarikan dan dikembangkan oleh generasi sesudahnya sesuai dengan dinamika tantangan hidup yang dihadapi oleh anak (Purwanto, 2011). 
Melalui pendidikan, peserta didik dapat meningkatkan potensi dasar yang dimilikinya baik itu potensi fisik, intelektual, emosional, mental, sosial, dan etika sehingga pendidikan merupakan hal penting yang harus didapatkan setiap peserta didik menuju terbentuknya peserta didik yang berkualitas. Dimana pada dasarnya pendidikan merupakan interaksi antara pendidik dengan peserta didik untuk mencapai tujuan pendidikan yang berlangsung dalam lingkungan pendidikan tertentu, serta memiliki fungsi untuk membantu peserta didik dalam pengembangan dirinya, yaitu pengembangan semua potensi, kecakapan, serta karakteristik pribadinya ke arah yang positif, baik bagi dirinya maupun lingkungannya.

Belajar merupakan suatu proses perubahan tingkah laku melalui pengalaman, yaitu perubahan tingkah laku individu, dimana perbedaannya terletak pada cara atau proses pencapaiannya yang mentikberatkan pada interaksi individu dengan lingkungannya. Belajar merupakan suatu proses perubahan tingkah laku melalui pengalaman, yaitu perubahan tingkah laku individu, dimana perbedaannya terletak pada cara atau proses pencapaiannya yang mentitikberatkan pada interaksi individu dengan lingkungannya. Proses belajar dalam upaya penambahan pengetahuan hanya sebagian kecil dari kegiatan menuju terbentuknya kepribadian seutuhnya (Suprijono, 2012).

Kurangnya pemahaman peserta didik terhadap konsep materi fisika disebabkan karena selama proses belajar mengajar berlangsung banyak peserta didik yang tidak memperhatikan apa yang dijelaskan oleh guru mata pelajaran atau hanya beberapa peserta didik yang memperhatikan. Peserta didik juga kurang aktif bertanya tentang konsep-konsep yang kurang dimengerti. Peserta didik cendrung melakukan aktivitas lain daripada memperhatikan guru yang sedang mengajar, sehingga pembelajaran cendrung berpusat pada guru. Hal ini terjadi karena ketertarikan peserta didik terhadap pelajaran fisika sangat kurang, ditambah lagi anggapan peserta didik terhadap fisika itu sulit dan membosankan karena penuh dengan persamaan-persamaan. Faktor-faktor tersebut dapat bersumber dari peserta didik sendiri maupun faktor luar. Faktor dari dalam diri peserta didik yakni kecerdasan, kesiapan dan bakat. Faktor dari luar peserta didik didominasi oleh lingkungan, salah satunya berupa kualitas pembelajaran yang didapatkan yang kemudian dipengaruhi oleh kemampuan (kompetensi) guru, suasana belajar, serta kepribadian guru.

Di sisi lain, guru sering menyajikan pembelajaran yang masih bersifat satu arah dari guru kepada murid melalui metode ceramah. Padahal terdapat metode pembelajaran lain yang sesuai dan dapat membuat proses belajar fisika peserta didik menjadi bermakna dan menyenangkan. Peserta didik yang tidak terlibat langsung dalam pembelajaran dan didominasi sepenuhnya oleh guru seharusnya menjadi suatu evaluasi bagi guru. Pembelajaran pada hakikatnya adalah kegiatan guru dalam membelajarkan peserta didik, sehingga proses pembelajaran adalah membuat peserta didik dalam kondisi belajar. Membuat peserta didik dalam kondisi belajar yang berarti perlu diciptakannya suatu suasana pembelajaran yang berpusat pada peserta didik dengan memberikan kesempatan kepada peserta didik untuk aktif dalam membangun pengetahuan tersebut. Hal tersebut tentunya muncul jika guru mau memberikan kesempatan kepada peserta didik untuk mengemukakan ide - ide atau gagasangagasannya.

Pembelajaran yang efektif merupakan hubungan yang cocok antara peserta didik dan lingkungan kelas (Yang \& Huang 2015). Beberapa konsep abstrak yang terdapat dalam pembelajaran fisika, menimbulkan kesulitan dalam memahami suatu materi yang diajarkan, baik oleh peserta didik maupun guru yang mengajar. Gunawan et al (2014) menyatakan bahwa beberapa konsep fisika termasuk konsep yang abstrak. Hal ini yang membuat peserta didik kurang aktif dalam berkomunikasi di kelas dan kreativitas fisika peserta didik rendah. Suranti et al (2016) menyatakan bahwa pentingnya seseorang menguasai suatu konsep adalah agar peserta didik mampu berkomunikasi, mengklasifikasikan ide, gagasan atau peristiwa yang dialaminya dalam kehidupan sehari-hari.

Pembelajaran pada peserta didik juga memerlukan suatu pekerjaan dalam kelompok sehingga dapat belajar dengan baik (Chen et al, 
2016). Peserta didik juga memiliki kemampuan pemecahan masalah dan jawaban dari permasalahan dengan pembagian waktu yang spesifik (Bashir et al 2016). Guru berperan penting dalam proses penyebaran pengetahuan yang inovatif ( $\mathrm{Wu} \&$ Looi, 2015). Menurut Sugiana et al (2016) bahwa peserta didik selalu memiliki gaya pembelajaran yang berbeda-beda serta penilaian berbeda mengenai pembelajaran yang sedang berlangsung.

Pada akhirnya pemilihan model pembelajaran yang sesuai dan lebih bervariasi serta proses pembelajaran yang berpusat pada peserta didik dapat menjadikan peserta didik berperan aktif dalam proses pembelajaran. Peningkatan kemampuan peserta didik dalam penguasaan konsep dapat membuat kreativitas peserta didik meningkat. Pemahaman topik ilmu yang kompleks terjadi dari penciptaan pemahaman informasi baru yang diperoleh peserta didik (Lee et al 2008). Permasalahan ini dapat diselesaikan dengan memilih model pembelajaran yang sesuai dengan kemampuan peserta didik. Pemilihan model pembelajaran yang sesuai dimaksudkan agar pembelajaran menjadi student centered dan guru tetap menjadi pembimbing sekaligus fasilitator dalam perkembangan peserta didik dalam mengemukakan pengetahuan dan pendapatnya. Salah satu model yang dapat diterapkan adalah Conceptual Understanding Procedures (CUPs) berbantuan LKPD.

Model pembelajaran CUPs merupakan model pembelajaran yang dapat mengaktifkan peserta didik secara langsung. Menurut Mckittrick (1999), model pembelajaran CUPs adalah prosedur pengajaran yang melibatkan peserta didik dalam diskusi tentang masalah fisika yang dikaitkan dalam konteks dunia nyata (kontekstual). Ismawati et al (2014) mengatakan model pembelajaran CUPs merupakan model pembelajaran yang terdiri atas serangkaian kegiatan pembelajaran dan bertujuan untuk meningkatkan pemahaman konsep peserta didik. Menurut Prastiwi et al (2014), model pembelajaran CUPs merupakan suatu model pembelajaran yang memberikan banyak peluang kepada peserta didik dalam mengkonstruksi pengetahuanya dari masalah dunia nyata (kontekstual).
Media pembelajaran dapat membangkitkan motivasi peserta didik untuk belajar dan sangat membantu keefektifan proses pembelajaran (Suranti et al, 2016). Salah satu alternatif media yang dapat digunakan adalah media lembar kerja peserta didik (LKPD). Perubahan nama LKS menjadi LKPD disebabkan oleh perubahan paradigma atau pandangan pendidikan tentang guru dan peserta didik. Penggunaan media LKPD bertujuan untuk memudahkan peserta didik dalam memahami konsep-konsep fisika, sebagai panduan dalam memecahkan suatu permasalahan, serta dapat mempermudah guru untuk menjelaskan konsepkonsep fisika tersebut. Pengantar pembelajaran fisika menggunakan bermacammacam konteks seperti media dapat membantu peserta didik belajar fisika (Mason \& Singh, 2016). LKPD merupakan salah satu media sebagai panduan peserta didik untuk melakukan kegiatan penyelidikan atau pemecahan masalah. Sehingga penggunaan model pembelajaran CUPs berbantuan LKPD ini memungkinkan peserta didik lebih aktif dalam pembelajaran khusunya di mata pelajaran fisika, sehingga mengoptimalkan hasil belajarnya.

Penelitian terkait dengan model pembelajaran CUPs antara lain dilakukan oleh Ismawati et al (2014) yang menyatakan bahwa model pembelajaran CUPs terbukti lebih efektif untuk meningkatkan pemahaman konsep dan curiosity peserta didik pada pelajaran fisika. Selain itu, Baidowi et al (2015) menemukan bahwa penerapan model pembelajaran CUPs dapat meningkatkan aktivitas dan hasil belajar matematika peserta didik kelas $X$ SMAN 7 Mataram tahun ajaran 2014/2015. Penelitian Anggreni et al (2013) menemukan bahwa model pembelajaran CUPs berpengaruh terhadap hasil belajar matematika pada peserta didik kelas V SD Gugus VII Komping Sujana, Denpasar Barat tahun ajaran 2012/2013.

Belum adanya penggunaan model pembelajaran CUPs yang digabungkan dengan media LKPD, serta dari beberapa penelitian terkait masih pada mata pelajaran bahasa, matematika dan kimia. Peneliti merasa tertarik untuk melakukan penelitian pada bidang studi fisika. Penggunaan model pembelajaran CUPs berbantuan LKPD cocok digunakan untuk menjadikan pembelajaran 
berpusat kepada peserta didik. Salah satu sekolah yang belum pernah menerapkan model CUPs adalah MA NW Narmada. Hal ini didukung dari hasil observasi, yang menunjukan bahwa pembelajaran di MA NW Narmada masih berpusat kepada guru. Peneliti berharap penggunaan model pembelajaran CUPs berbantuan LKPD mampu meningkatkan kreativitas peserta didik pada pembelajaran fisika di tingkat sekolah menengah atas.

\section{TINJAUAN PUSTAKA.}

\section{A. Pembelajaran Conceptual Understanding Procedures (CUPs)}

Menurut Mills et al (1999), model pembelajaran CUPs adalah prosedur pengajaran yang melibatkan peserta didik dalam diskusi tentang masalah fisika yang dikaitkan dalam konteks dunia nyata (kontekstual). Menurut Prastiwi et al (2014), model pembelajaran CUPs merupakan model pembelajaran yang dirancang untuk membantu perkembangan pemahaman peserta didik menemukan konsep yang sulit. Model CUPs menggunakan pendekatan kontruktivis, yaitu berdasarkan keyakinan bahwa peserta didik membangun pemahaman konsep mereka sendiri dengan memodifikasi atau memperluas pengetahuan yang sudah ada.

Menurut Loughran et al (2012), langkahlangkah yang terdapat dalam model pembelajaran CUPs yaitu: peserta didik bekerja sendiri selama beberapa menit dengan tugas yang diberikan secara individu, peserta didik duduk sesuai kelompok yang beranggotakan tiga atau empat orang dan berusaha berdiskusi untuk mencari jawaban tugas individu dalam kelompok, mempresentasikan hasil diskusi kelompok didepan kelas dan ditanggapi oleh kelompok yang lain dengan tujuan untuk mendapatkan kesimpulan yang terbaik. Ismawati et al (2014), mengatakan ada tiga fase pembelajaran CUPs adalah, fase kerja individu, fase kerja kelompok, dan fase presentasi hasil kerja kelompok.

\section{B. Lembar Kerja Peserta Didik (LKPD)}

Lembar kegiatan peserta didik (LKPD) dapat berupa panduan untuk latihan pengembangan aspek kognitif maupun panduan untuk mengembangkan semua aspek pembelajaran dalam bentuk panduan eksperimen atau demonstrasi (Sahidu, 2013). Hal ini sejalan dengan Hermansyah et al (2015) yang menyatkan bahwa praktek penggunaan LKPD atau yang sering diebut LKS merupakan kumpulan materi, contoh soal, dan latihan soal. LKPD dalam hal ini sama dengan LKS, hanya saja istilah penyebutannya yang berbeda.

LKS yaitu materi ajar yang sudah dikemas sedemikian rupa, sehingga peserta didik diharapkan dapat mempelajari materi ajar tersebut secara mandiri (Damayanti 2013). Hal ini didukung oleh Lubis \& Lestari (2017) yang menyatkan bahwa LKS merupakan media pembelajaran yang dapat dikembangkan oleh guru, yang berperan sebagai fasilitator dalam kegiatan pembelajaran. LKS digunakan sebagai acauan atau memandu pelaksanaan kegiatan pembelajaran dan juga sebagai alat pembelajaran (Sukmawati \& Lestari, 2017). Peneliti berpendapat bahwa LKPD memiliki beberapa fungsi diantaranya yaitu: sebagai bahan ajar yang bisa meminimalkan peran guru, namun lebih mengaktifkan peserta didik, sebagai petunjuk untuk peserta didik dalam mengerjakan tugas yang diberikan, serta mempermudah pelaksanaan pembelajaran.

\section{Kreativitas}

Menurut Guilford (2012), kreativitas atau berpikir kreatif sebagai kemampuan untuk melihat bermacam-macam kemungkinan penyelesaian terhadap suatu masalah, merupakan bentuk pemikiran yang sampai saat ini masih kurang mendapat perhatian dalam pendidikan. Makmur \& Thahier (2015) menyatakan bahwa kreativitas adalah segala sesuatu yang dihasilkan oleh manusia yang menggunakan pemikiran dan tenaga fisik yang dilakukan secara terus-menerus serta bermanfaat bagi kehidupan manusia. Ekasari et al (2016) menyatakan bahwa kreativitas merupakan kemampuan seseorang untuk menghasilkan suatu produk yang baru ataupun kombinasi dari hal-hal yang sudah ada sebelumnya, yang berguna, serta dapat dimengerti. Peneliti menyimpulkan bahwa kreativitas adalah kemampuan yang dimiliki peserta didik untuk menyelesaikan suatu permasalahan dari pengetahuan yang dimilikinya untuk menemukan banyak kemungkinan jawaban terhadap suatu masalah, dengan menggunakan alat ukur kreativitas, yaitu tes kreativitas verbal dan figural. 
Munandar (2012) mengatakan bahwa kreativitas merupakan suatu konstruk yang multidimensional, terdiri dari berbagai dimensi, yaitu dimensi kognitif (berpikir kreatif), dimensi afektif (sikap dan kepribadian), dan dimensi psikomotor (keterampilan kreatif).

\section{METODE}

Penelitian kuasi eksperimen ini menggunakan desain non-equivalent control group design. Penelitian ini melibatkan variabel bebas, yaitu model pembelajaran CUPs berbantuan LKPD dan variabel terikat yaitu kreativitas, serta variabel kontrol yaitu waktu dan bahan ajar. Penelitian ini dilakukan di MA NW Narmada. Sampel dipilih secara purposive sampling. Purposive sampling adalah teknik penentuan sampel dengan pertimbangan tertentu (Sugiyono, 2012).

Pada penelitian ini, instrumen yang digunakan adalah tes kreativitas yaitu berupa tes kreativitas verbal (TKV) dan tes kreativitas figural (TKF). Tes kreativitas verbal berjumlah 5 soal dan tes kreativitas figural sebanyak 5 soal. Indikator yang digunakan dalam tes kreativitas ini adalah kelancaran (fluency), keluwesan (flexibility), keaslian (originality), terperinci (elaboration) (Munandar, 2012).

Instrumen tes kreativitas baik TKV dan TKF sebelum digunakan pada tes awal dan tes akhir divaliditas ahli. Uji hipotesis menggunakan uji-t polled varian, setelah sebelumnya dilakukan uji homogenitas dan uji normalitas sebaran data.

Dalam pelaksanaan model CUPs berbantuan LKPD di kelas peserta didik dihadapkan kepada suatu lembar kerja individu yang diawali dengan guru memberikan suatu permasalah dengan mengambil masalah sesuai dengan dunia nyata. Guru meminta peserta didik membuat pertanyaan dan jawaban dari pertanyaan tersebut terkait demonstrasi. Selanjutnya guru bersama peserta didik membuat kelompok dan memberikan lembar kerja kelompok. Guru membimbing, menilai dan meminta peserta didik untuk melakukan suatu percobaan, meminta peserta didik untuk berdiskusi dan menyimpulkan secara kelompok hasil diskusi, eksperimen dan mengisi di lembar kerja kelompok. Guru meminta perwakilan masing-masing kelompok untuk mempresentasikan hasil kerja kelompok di depan kelas. Pada akhir pembelajaran guru menyampaikan dan menyimpulkan pembelajaran.

Pembelajaran CUPs dengan media LKPD di kelas dapat dibagi menjadi tiga fase sesuai dengan alokasi waktu yang disiapkan, yaitu pertama, fase kerja individu; kedua, fase kerja kelompok; ketiga, fase presentasi hasil kerja kelompok (Ismawati et al, 2014). Pada fase kerja individu, peserta didik diberikan lembar kerja individu dan diminta untuk membuat pertanyaan dan jawaban dari pertanyaan tersebut terkait dengan demonstrasi yang diberikan. Pada fase ini peserta didik diajak untuk mengemukakan pengetahuan awalnya sebelum membuktikannya melalui suatu percobaan. Kemudian fase kerja kelompok peserta didik diorganisaikan dalam kelompok dan guru membimbing, menilai dan meminta peserta didik untuk melakukan suatu percobaan serta memberikan lembar kerja kelompok. Selanjutnya fase terakhir yaitu presentasi hasil kerja kelompok. Pada fase ini guru meminta perwakilan setiap kelompok untuk mempresentasikan hasil kerja kelompok didepan kelas.

Tes kreativitas diberikan sebelum dan sesudah perlakuan dan selanjutnya dihitung peningkatan kreativitas pada kedua kelas, baik secara umum maupun pada setiap tes kreativitas verbal dan figural. Peningkatan kreativitas peserta didik ditentukan dari besarnya skor gain yang dinormalisasi (N-gain) dengan persamaan (Sundayana, 2014).

$$
\mathrm{N}-\text { gain }=\frac{\mathrm{S}_{\text {post }}-\mathrm{S}_{\text {pre }}}{\mathrm{S}_{\max }-\mathrm{S}_{\text {pre }}} \times 100 \%
$$

Dengan kategori perolehan N-gain berikut.

Tabel 1. Kriteria Perolehan N-gain

\begin{tabular}{lcl}
\hline No. & Interval & Kriteria \\
\hline $\mathbf{1}$ & $\mathrm{g}>70$ & Tinggi \\
$\mathbf{2}$ & $30 \leq \mathrm{g} \leq 70$ & Sedang \\
$\mathbf{3}$ & $\mathrm{g}<30$ & Rendah \\
\hline
\end{tabular}

\section{HASIL DAN PEMBAHASAN}

Penelitian ini bertujuan untuk mengetahui pengaruh model conceptual understanding procedures berbantuan LKPD terhadap kreativitas peserta didik dalam pembelajaran fisika. Kreativitas 
yang diukur meliputi kreativitas verbal dan figural. Materi yang digunakan pada penelitian ini yaitu suhu dan kalor dengan sub materi kalor, pemuaian, perpindahan kalor dan asas black. Sebelum diberikan ke peserta didik, tes kreativitas sudah di validasi ahli dengan kategori baik. Data tentang hasil kemampuan peserta didik sebelum dan sesudah perlakuan diperoleh melalui tes awal dan tes akhir pada TKV dan TKF. Kemampuan kreativitas peserta didik sebelum dan sesudah diberikan perlakuan terlihat dari skor tes awal dan tes akhir yang disajikan dalam Gambar1 berikut.

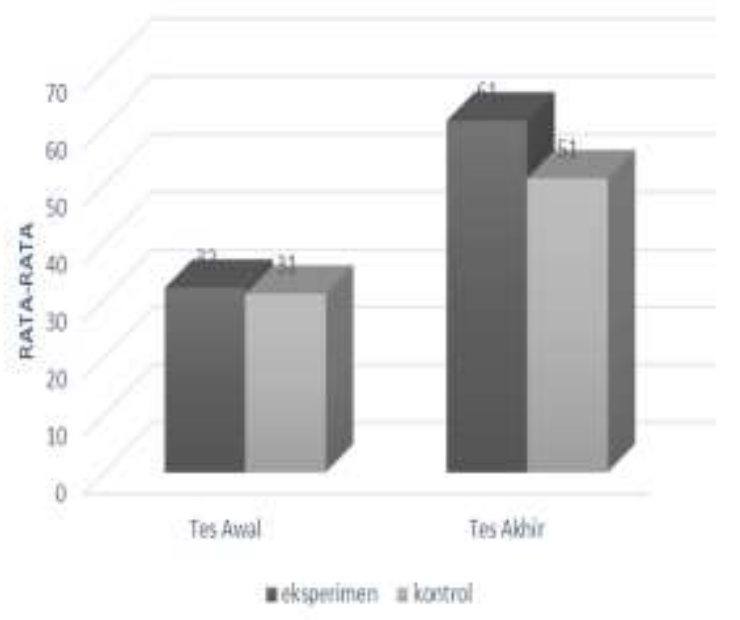

Gambar 1. Perbandingan Kreativitas Peserta Didik

Data kemampuan awal yang digunakan dalam penelitian ini adalah data hasil dari tes awal (pretest) peserta didik sebelum diberikan perlakuan.

Tes awal diberikan untuk mengetahui homogenitas dan normalitas kreativitas awal peserta didik pada kelas eksperimen dan kelas kontrol. Data tes awal menunjukkan bahwa kemampuan kreativitas awal pada kedua kelas hampir sama. Rata - rata nilai kelas eksperimen 32 dan kelas kontrol 31. Tes awal peserta didik pada kedua kelas memiliki skor yang rendah. Dari uji homogenitas data tes awal yang telah dilakukan didapat hasil nilai $\mathrm{F}_{\text {hitung }}<\mathrm{F}_{\text {tabel }}$ yang berarti data tes awal kedua kelas adalah homogen.

Data kemampuan akhir yang diperoleh pada penelitian ini adalah data setelah diberikan perlakuan. Hasil tes mengalami peningkatan yang ditunjukkan oleh rata-rata tes akhir yang lebih tinggi dari sebelumnya. Rata - rata nilai kelas eksperimen 61 dan kelas kontrol 51. Tes akhir peserta didik pada kedua kelas mengalami peningkatan dari tes awal. Hal ini dapat diketahui dari nilai rata-rata yang diperoleh kelas eksperimen lebih tinggi dibanding kelas kontrol. Hal ini disebabkan karena penggunaan model pembelajaran CUPs berbantuan LKPD dapat membantu peserta didik dalam mengintegrasikan pengetahuan barunya dari pengetahuan sebelumnya sehingga dapat membantu dalam berpikir kreatif. Secara lebih terperinci terkait hubungan nilai antara tes awal dan tes akhir untuk data nilai tertinggi, terendah dan nilai rata-rata digambarkan dalam Gambar 2 berikut.

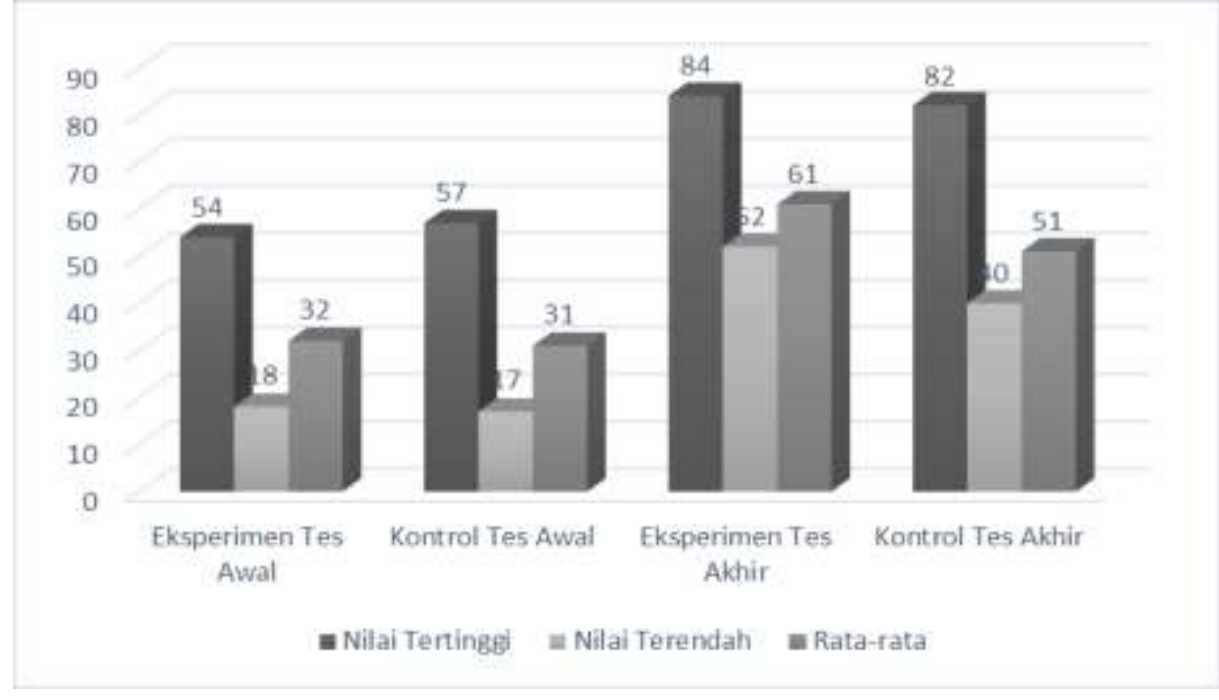

Gambar 2. Perbandingan Peningkatan Kelas Eksperimen dan

Kelas Kontrol Setelah Pre-Test dan Post-Test 
Perbandingan peningkatan kelas eksperimen dan kelas kontrol menunjukkan bahwa kemampuan awal kedua kelas sama, dilihat dari nilai tertinggi dan terendah yang didapatkan kedua kelas. Setelah diberikan perlakuan kedua kelas mengalami peningkatan, akan tetapi kelas eksperimen mengalami peningkatan lebih tinggi dibandingkan dengan kelas kontrol.

Pengujian data kreativitas peserta didik untuk kelas eksperimen dan kelas kontrol tes awal dan tes akhir diawali dengan uji homogenitas kedua data, yang dilanjutkan dengan uji normalitas, dan terakhir uji hipotesis menggunakan uji-t polled varians.

Selanjutnya dilakukan uji normalitas data tes awal dan tes akhir pada masing - masing kelas pada kelas kontrol didapatkan bahwa $\chi_{\text {hitung }}^{2}<\chi_{\text {tabel }}^{2}$ yakni $7,630<12,592$, sedangkan pada kelas eksperimen didapatkan bahwa $\chi_{\text {hitung }}^{2}<\chi_{\text {tabel }}^{2}$ yakni 5,860 $<12,592$.

Dari hasil ini disimpulkan bahwa data tes kreativitas pada kedua kelas terdistribusi normal. Selanjutnya dilakukan uji hipotesis menggunakan uji-t polled varian. Hasil uji hipotesis menunjukkan bahwa nilai $t_{\text {hitung }}>t_{\text {tabel }}(4,25>2,00)$ sehingga dapat disimpulkan bahwa terdapat pengaruh model conceptual understanding procedures berbantuan LKPD terhadap kreativitas peserta didik dalam pembelajaran fisika. Model conceptual understanding procedures yang dipadukan dengan LKPD memberikan pengaruh positif terhadap peningkatan kreativitas peserta didik pada kelas eksperimen.

Selain melakukan uji hipotesis peneliti juga ingin mengetahui sejauh mana peningkatan yang dialami kedua kelas secara lebih terperinci terkait hubungan kelas kontrol dan kelas eksperimen. Perbandingan persentase kenaikan kreativitas peserta didik pada tes kreativitas verbal dan figural untuk kedua kelas dicari dengan menghitung skor $\mathrm{N}$-gain kedua kelas, sebagaimana yang ditunjukkan pada Gambar 3 berikut.

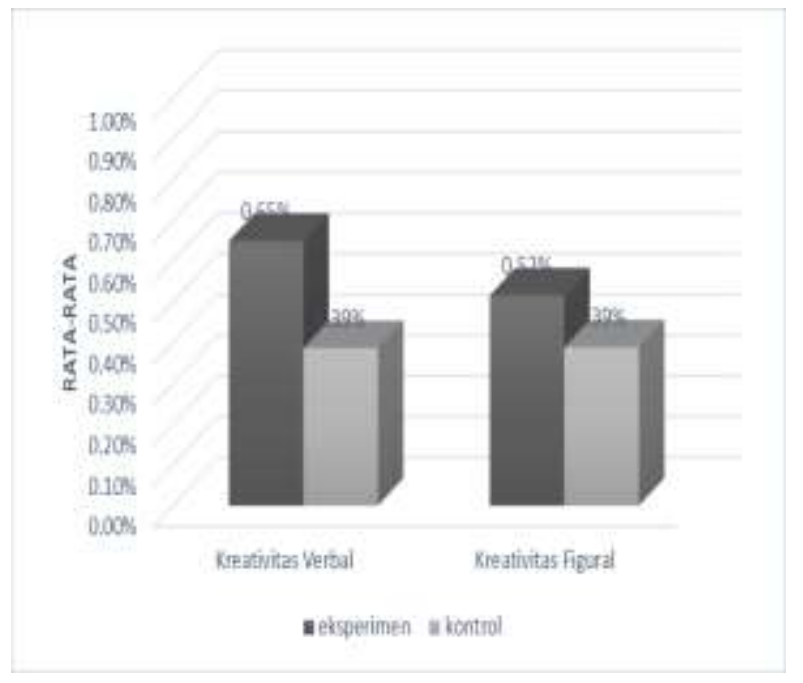

Gambar 3. Perbandingan Peningkatan Kreativitas Verbal dan Figural pada Kedua Kelas

Dari gambar 3 dapat diketahui bahwa peningkatan kreativitas verbal lebih tinggi dibandingkan kreativitas figural. Hasil ini diperkuat dengan hasil penelitian sebelumnya yang dilakukan oleh Gunawan et al (2017) yang menemukan bahwa hasil tes kreativitas verbal yang lebih tinggi menunjukkan bahwa kemampuan peserta didik lebih tinggi dalam berpikir secara divergen untuk mengkombinasikan ide secara verbal terhadap suatu persoalan yang tercermin dari kelancaran, kelenturan dan orisinilitas dalam berpikir dibandingkan dengan kemampuan peserta didik untuk mengasosiasikan idenya melalui bentuk atau gambar.

Peningkatan kreativitas verbal yang lebih tinggi juga disebabkan karena tingkatan soal berbeda. Tes kreativitas verbal lebih mudah untuk diselesaikan oleh peserta didik karena hanya membutuhkan kelancaran dalam mengajukan gagasan-gagasan. Sedangkan tes kreativitas figural membutuhkan konsentrasi yang tinggi untuk menjawab soal, karena peserta didik diminta untuk memberikan keterangan pada gambar dan melengkapi gambar menjadi suatu gambar tunggal yang bermakna. 
Kemampuan akhir pada kedua kelas meningkat, akan tetapi peningkatan kelas eksperimen lebih tinggi dibandingkan dengan kelas kontrol. Hal ini disebabkan karena perlakuan yang diberikan kepada kelas eksperimen dan kelas kontrol berbeda. Pada kelas eksperimen diterapkan model pembelajaran CUPs berbantuan LKPD, sedangkan kelas kontrol menggunakan model pembelajaran tanpa bantuan LKPD. Dimana pada pembelajaran CUPs peserta didik diaktifkan secara langsung melalui fase - fase CUPs yang ada yaitu mulai dari fase kerja individu, fase kerja kelompok dan fase presentasi hasil kerja kelompok. Pada fase kerja individu peserta didik diminta untuk menjawab LKPD secara individu, kemudian duduk berdasarkan kelompok yang sudah dibagikan yang terdiri dari sebanyak 4-5 orang, kemudian diberikan LKPD kelompok yang akan dijawab secara berkelompok, pada fase ini peserta didik melakukan praktikum dan fase yang terakhir yaitu fase presentasi hasil kerja kelompok. Pada fase ini setiap kelompok mempresentasikan hasil kerja kelompok di depan kelas. Hal ini dilakukan untuk lebih mengaktifkan peserta didik secara langsung dan mampu membantu peserta didik dalam mengembangkan kemampuan berpikir kreatif.

Secara umum, terdapat peningkatan kreativitas pada kedua kelas. Akan tetapi kreativitas verbal lebih meningkat dibandingkan kreativitas figural. Hal ini dilihat dari presentasi Ngain yang diperoleh untuk kelas eksperimen dan kelas kontrol. Kelas eksperimen mengalami peningkatan lebih tinggi yaitu $65 \%$ pada tes kreativitas verbal dan $53 \%$ pada tes kreativitas figural. Sedangkan kelas kontrol pada kedua tes mendapatkan presentasi yang sama yaitu $39 \%$. Sehingga dapat disimpulkan bahwa kemampuan pada kelas kontrol sama untuk kedua tes. Besarnya peningkatan kreativitas pada kedua kelas ini juga dapat dilihat dari rata-rata nilai $\mathrm{N}$-gain yang diperoleh. Kelas eksperimen memiliki nilai ratarata sebesar $55 \%$, lebih tinggi dibandingkan kelas kontrol yang hanya mendapatkan rata-rata sebesar $39 \%$. Peningkatan pada kedua kelas berada pada kategori sedang. Peningkatan yang lebih tinggi pada kelas eksperimen disebabkan adanya perlakuan berupa model CUPs berbantuan media
LKPD. Hasil ini diperkuat oleh hasil penelitian sebelumnya yang dilakukan oleh Gunawan et al (2017) yang menemukan bahwa peningkatan Ngain pada kedua kelas berada pada kategori sedang.

Hasil penelitian dengan menggunakan model CUPs ini memperkuat beberapa pendapat sebelumnya. Makmur \& Thahier (2015) menyatakan bahwa kreativitas adalah segala sesuatu yang dihasilkan oleh manusia yang menggunakan pemikiran dan tenaga fisik yang dilakukan secara terus-menerus serta bermanfaat bagi kehidupan manusia. Hasil penelitian Gummah et al (2013) menemukan bahwa penerapan model pembelajaran kooperatif teknik CUPs dapat meningkatkan hasil belajar dan aktivitas peserta didik kelas VIII SMP 13 Mataram 2013 / 2014. Baidowi et al (2014) menemukan bahwa penerapan model pembelajaran Conceptual Understanding Procedures (CUPS) dapat meningkatkan aktivitas dan hasil belajar matematika peserta didik kelas X MIA 1 SMA Negeri 7 Mataram tahun ajaran 2014/2015. Penelitian Hidayati \& Sinulingga (2015) juga menemukan bahwa ada perbedaaan siginifikan akibat pengaruh model pembelajaran CUPs terhadap hasil berlajar peserta didik pada materi pokok listrik dinamis di kelas X. Menurut Siswanto et al (2013), implementasi CUPs dapat meningkatkan kemampuan kognitif $\mathrm{C} 2$ peserta didik yang berpengaruh besar terhadap peningkatan hasil belajar peserta didik. Hal ini ditunjukkan dengan meningkatnya rata-rata nilai peserta didik.

\section{KESIMPULAN}

Kreativitas merupakan kemampuan kognitif peserta didik dalam menemukan begitu banyak jawaban dari permasalahan yang diperoleh. Berdasarkan hasil penelitian dan pembahasan, dapat disimpulkan bahwa ada pengaruh model pembelajaran conceptual understanding procedures (CUPs) berbantuan LKPD terhadap berpikir kreatif peserta didik. Kelas eksperimen yang diberi perlakuan berupa model pembelajaran CUPs berbantuan LKPD memperoleh skor rata rata kreativitas yang lebih tinggi dibandingkan 
dengan kelas kontrol yang diberikan perlakuan berupa pembelajaran langsung tanpa bantuan LKPD. Kedua kelas mengalami peningkatan kemampuan kreativitas pada kategori sedang. Kreativitas verbal dan figural pada kelas eksperimen lebih tinggi dibandingkan kelas kontrol. Berdasarkan hasil uji hipotesis dapat dibuktikan bahwa terdapat perbedaan kreativitas fisika antara kelas eksperimen yang diberikan perlakuan berupa penggunaan model CUPs berbantuan LKPD dengan kelas kontrol yang diberikan perlakuan berupa penerapan model pembelajaran langsung tanpa bantuan LKPD pada peserta didik kelas X MA NW Narmada tahun ajaran 2016/2017.

\section{PUSTAKA}

Anggreni, K. R., Meter, I. G., \& Wiarta, I. W. (2013). Model Pembelajaran Conceptual Understanding Procedures Berpengaruh Terhadap Hasil Belajar Matematika Siswa Kelas V SD Gugus VII Kompiang Sujana Denpasar Barat. Mimbar Pgsd, 1, 12-21.

Baidowi., Hikmah, N., Kurniawati, N. 2014. Penerapan Model Pembelajaran Conceptual Understanding Procedures (CUPs) untuk Meningkatkan Aktivitas dan Hasil Belajar Siswa. Jurnal Pijar Mipa. 1 $: 85$.

Bashir, G. M. M., Hoque1, A. S. M. L., \& Nath. B. C. D. 2016. E-learning of PHP Based on the Solutions of Real-Life Problems. $J$. Comput. Educ. 3(1): 105-129.

Chen, C. J., Keong, M. W. Y., Teh, C. S., \& Chuah, K. M. 2016. Web Text Reading: What Satisfy Both Dyslexic and Normal Learners?. J. Comput. Educ. 3(1): 47-58.

Damayanti, D. S. (2013). Pengembangan Lembar Kerja Siswa (LKS) Dengan Pendekatan Inkuiri Terbimbing Untuk Mengoptimalkan Kemampuan Berpikir Kritis Peserta Didik Pada Materi Listrik Dinamis SMA Negeri 3 Purworejo Kelas $\mathrm{X}$ Tahun Pelajaran 2012/2013. RADIASI: Jurnal Berkala Pendidikan Fisika, 3(1), 58-62.

Ekasari, R. R., Gunawan, G., \& Sahidu, H. (2016). Pengaruh Model Pembelajaran Langsung Berbantuan Media Laboratorium Terhadap Kreatifitas Fisika Siswa SMA. Jurnal
Pendidikan Fisika dan Teknologi,2(3), 106-110.

Guildford. 2012. Pengembangan Kreativitas Anak . Jakarta: Rineka Cipta.

Gummah, S., Soraya, L., Ahzan, S., dan Hardiyanti. 2013 . Penerapan Model Pembelajaran Teknik Conceptual Understanding Procedures untuk Meningkatkan Hasil Beljara dan Aktivitas Siswa. Jurnal Pengkajian Ilmu dan Pembelajaran. $2: 5$.

Gunawan, G., Harjono, A., \& Sutrio, S. (2015). Multimedia Interaktif dalam Pembelajaran Konsep Listrik bagi Calon Guru. Jurnal Pendidikan Fisika dan Teknologi, 1(1), 914.

Gunawan, G., Setiawan, A., \& Widyantoro, D. H. (2014). Model Virtual Laboratory Fisika Modern untuk Meningkatkan Keterampilan Generik Sains Calon Guru. Jurnal Pendidikan dan Pembelajaran (JPP), 20(1), 25-32.

Gunawan., Sahidu, H., Harjono,H., \& Suranti, N. M. Y. (2017). The Effect Of Project Based Learning With Virtual Media Assitance On Student's Creativity In Physics. Jurnal Cakrawala Pendidikan, Th, XXXVI, No.2.

Hermansyah, H., Gunawan, G., \& Herayanti, L. (2015). Pengaruh Penggunaan Laboratorium Virtual Terhadap Penguasaan Konsep dan Kemampuan Berpikir Kreatif Siswa pada Materi Getaran dan Gelombang. Jurnal Pendidikan Fisika dan Teknologi, 1(2), 97-102.

Hidayati, F., \& Sinulingga, K. (2015). Pengaruh Model Pembelajaran Conceptual Understanding Procedures (Cups) Terhadap Hasil Belajar Siswa Pada Materi Pokok Listrik Dinamis Di Kelas X Semester II SMA Negeri 1 Binjai TP 2014/2015. INPAFI (Inovasi Pembelajaran Fisika), 3(4), 59-66.

Ismawati., Nugroho, P., dan Dwijananti. 2014. Penerapan Model Pembelajaran Conceptual Understanding Procedures untuk Meningkatkan Curiosty dan Pemahaman Konsep Siswa. Jurnal Pendidikan Fisika Indonesia. 10: 22-23.

Lee, H. W., Lim, K. Y., \& Grabowski, B. L. (2008). Generative learning: Principles and 
implications for making meaning. In $\mathrm{M}$. Specter, M. D. Merrill, J. J. G. van Merrienboer \& M. P. Driscoll (Eds.), Handbook of research on educational communications and technology (3rd ed.). New York, NY: Taylor \& Francis Group.

Loughran, J.,Berry, A., dan Mulhall, P.,2012. Understanding and Developing Science Teachers' Pedagogical Content Knowledge $2^{\text {nd }}$ Edition. Monash University: Sense Publishers.

Lubis, R. R., \& Lestari, R. (2017). Pengembangan Lembar Kerja Siswa Berbasis Inkuiri Untuk Kelas Viii Smp Negeri 5 Rambah Samo Pada Materi Gerak Pada Tumbuhan. Jurnal Ilmiah Mahasiswa FKIP Prodi Biologi, 3(1).

Makmur., dan Thahier, R. 2015. Inovasi Kreativitas Manusia. Makassar: PT Refika Aditama.

Mason, A., \& Singh, C. 2016. Using Categorization of Problems as an Instructional Tool to Help Introductory Students Learn Physics. Physc. Educ. 50: 1-6.

Mills, D., Mckittrick, B., Mulhall, P., dan Feteris, S. 1999. CUP: Cooperative Learning that Works. Physics Education. 34 (1): 11-16.

Munandar, U. 2012. Pengembangan Kreativitas Anak Berbakat. Jakarta: Rineka Cipta.

Prastiwi, I., Soedjoko, E., dan Mulyono. 2014. Efektivitas Pembelajaran Conceptual Understanding Procedures untuk Meningkatkan Kemampuan Siswa pada Aspek Koneksi Matematika. Jurnal Krean. 5(1): 42.

Purwanto. 2011. Evaluasi Hasil Belajar. Yogyakarta: Pustaka Belajar.

Sahidu, C. 2013. Pengembangan Program Pembelajaran Fisika (P3F). Mataram: FKIP PRESS Universitas Mataram.

Siswanto, B., Sriyono, dan Maftukhin, A. 2013. Implementasi Model Conceptual Understanding Procedures (CUPs) dalam Pembelajaran Fisika untuk Meningkatkan Kemampuan Kognitif C2 Siswa Kelas X SMK YPT Purworejo. Radiasi. 4 (1): 38.

Sugiana, I. N., Harjono, A., Sahidu, H., \& Gunawan, G. (2016). Pengaruh Model
Pembelajaran Generatif Berbantuan Media Laboratorium Virtual Terhadap Penguasaan Konsep Fisika Siswa pada Materi Momentum dan Impuls. Jurnal Pendidikan Fisika dan Teknologi, 2(2), 61-65.

Sugiyono. 2012. Statistika Untuk Penelitian. Bandung: Alfabeta.

Sukmawati, N. A., \& Lestari, R. (2017). Pengembangan Lembar Kerja Siswa Berbasis Inkuiri Terbimbing Untuk Kelas VII SMP Muhammadiyah Rambah Pada Materi Pencemaran Dan Kerusakan Lingkungan. Jurnal Ilmiah Mahasiswa FKIP Prodi Biologi, 3(1).

Sundayana, R. 2014. Statistika Penelitian Pendidikan. Bandung: Alfabeta.

Suprijono, A. 2012. Cooperative Learnig Teori dan Aplikasi Paikem. Yogyakarta: Pustaka Pelajar.

Suranti, N. M. Y., Gunawan, G., \& Sahidu, H. (2016). Pengaruh Model Project Based Learning Berbantuan Media Virtual Terhadap Penguasaan Konsep Peserta didik pada Materi Alat-alat Optik. Jurnal Pendidikan Fisika dan Teknologi,2(2), 73-79.

Trianto. 2011. Model Pembelajaran Terpadu. Jakarta: Bumi Aksara.

Wu, L., Ye, X., \& Looi, C. K. 2015. Teachers' Preflection in Early Stages of Diffusion of an Innovation. J. Comput. Educ. 2(1): $1-24$.

Yang, J., \& Huang, R. 2015. Development and validation of a scale for evaluating technology-rich classroom environment. J. Comput. Educ. 2(2): 145-162. 